\title{
Properties of kukersite shale oil
}

\author{
Oliver Järvik, Zachariah Steven Baird*, Rivo Rannaveski, Vahur Oja
}

Department of Energy Technology, Tallinn University of Technology, Ehitajate tee 5, 13006 Tallinn, Estonia

Received 7 December 2020, accepted 10 November 2021, available online 10 December 2021

\begin{abstract}
Despite the increasing focus on reducing carbon dioxide emissions, the production of shale oil continues to be economically favorable and has even increased in recent years. Producing and handling shale oil requires data on its properties, and to provide this data the authors have undertaken an extensive project to experimentally measure the properties of Estonian kukersite shale oil. In this article we describe the sample preparation methods and present experimental data on key properties of the shale oil samples. Included is data on the densities, refractive indexes, average boiling points, and molar masses of distillation fractions with narrow boiling ranges. A major component of kukersite shale oil is phenolic compounds, and to investigate their effect on the properties we used extraction to obtain samples with either fewer or more phenols than commonly found in the oil. The effect of composition on the properties is discussed. We also present correlations for calculating one of these properties if two others are known. This article lays the groundwork for future articles which will go into further details on specific properties of these samples.
\end{abstract}

Keywords: kukersite oil shale, shale oil, fuel, thermophysical properties, phenols.

\section{Introduction}

Shale oil is a liquid fossil fuel obtained from pyrolysis of oil shale [1, 2]. Although fossil fuels have negative environmental impacts, which will likely limit their use long term, in the short term the demand for oil is actually expected to increase, especially due to increased demand in developing countries [3, 4]. For this reason, shale oil and other fossil fuel resources still play an important economic role. As evidence of this, in the past decade both Eesti Energia and VKG have constructed new shale oil plants in Estonia [5-8].

\footnotetext{
* Corresponding author: e-mail zachariah.baird@taltech.ee

(C) 2021 Authors. This is an Open Access article distributed under the terms and conditions of the Creative Commons Attribution-NonCommercial 4.0 International License (http://creativecommons.org/licenses/by-nc/4.0/).
} 
Oil shale is a solid fossil fuel that consists of organic matter (kerogen) dispersed in a mineral matrix [1,2, 9-12]. From time to time oil shale receives attention due to the large reserves present in deposits around the world [12]. It has been estimated that 6 trillion barrels of oil could be produced from known oil shale resources, which is about 4 times larger than conventional petroleum resources [4]. Due to economic and environmental problems, oil shale has not seen widespread use $[13,14]$. However, oil shale industries do exist in some parts of the world, including Brazil, China, and Estonia [15]. Other countries, such as Jordan and Morocco, have also shown interest in developing their oil shale resources, and in Jordan construction of an oil shale fired power plant is nearing completion $[16,17]$.

By heating the oil shale under the appropriate conditions (termed pyrolysis), an oil, shale oil, is produced $[1,2]$. Note that this shale oil should not be confused with tight oil (also called shale oil), which is simply conventional oil trapped in a shale formation that is obtained using hydraulic fracturing [18]. The shale oil produced from oil shale is a mixture of many different organic compounds. The exact composition can vary greatly depending on the type of oil shale used and the pyrolysis conditions (e.g. reactor type, heating rate, temperature, residence time, particle size) [12, 19-21].

Information on the properties of shale oil (and chemicals in general) is essential for designing and operating plants and also for evaluating the environmental and health hazards posed by the oil. However, there is little data on the thermophysical properties of kukersite shale oil, and most of that data was measured decades ago for oil produced in older retorts (mainly tunnel ovens and generator retorts) [22]. For that reason this project was undertaken. This study provides thorough new experimental data on the properties of different shale oil fractions. Specifically, data on the densities, average boiling points, molar masses, refractive indexes (RI), and compositions of shale oil fractions is given here. We also used vacuum distillation to recover heavier fractions of the oil that have not been measured in earlier studies. Experimental data on other properties, including vapor pressures, viscosities, surface tensions, sulfur contents, nitrogen contents, pour points, and enthalpies of combustion, will be given in future articles. The data in this article also enables the development of modern correlations and models for predicting the properties of shale oil. Toward that aim we here present simple correlations for predicting some basic properties of kukersite oil shale fractions if two other basic properties are known.

\section{Kukersite shale oil}

To better understand the different samples measured in this study, it is helpful to have some basic information about the processes used to produce shale oil and the chemical composition underlying the properties of the oil. 
Estonia has two types of oil shale: kukersite and dictyonema argillite [23]. Dictyonema argillite has a lower organic content, and thus, has not been used commercially. Kukersite oil shale, however, has a higher organic content of about $32-38 \%$, and has been used for shale oil production since the mid-1920s [24-27].

A wide variety of retorting methods (i.e. pyrolysis methods) have been invented for producing oil from oil shale. They can be broadly classified as in situ (below ground) and ex situ (above ground) methods. In situ experiments were conducted in the Kiviõli mine in Estonia many decades ago, but it was abandoned due to the high work load required, low oil yield, and environmental impact [23]. To date all commercial oil shale production has been performed ex situ in industrial plants. Shale oil has been commercially produced in Estonia for almost a century, and five main types of industrial retort have been used: chamber oven, tunnel oven, rotating retort, generator retort and solid heat carrier retort [23, 25, 28]. A fusion retort was also briefly used [23, 25]. Additionally, we describe a widely used laboratory retorting method called the Fischer assay. The basic properties of oil from each industrial retort are given in Table 1.

\subsection{Fischer assay}

The Fischer assay is used to estimate the oil yield of a given oil shale. It was originally intended for use in the coal industry, but has also been adopted for use with oil shale. The yields for industrial retorts are often compared to the Fischer assay results.

Fischer assay is meant to be a standard method, and several standards exist for it. An oil shale sample is crushed to a prescribed mesh size, and then a specific mass of the sample is heated in a small lab-scale retort. The heating rate and heating times are prescribed by the standards. It has been shown that variations in the assay procedure can give different results and a different oil [29].

Much of the data about shale oils is for oil produced in a Fischer assay because this process can be done in a lab without the investment needed for a commercial retort.

\subsection{Chamber oven}

In a chamber oven the oil shale was heated in a chamber made of fireproof bricks. The main goal was to produce gas with a high heating value, and to achieve this the oil shale was heated quickly to $900{ }^{\circ} \mathrm{C}$. The retort used oil shale pieces that were $25-100 \mathrm{~mm}$ in size. The oil obtained from this type of retort was a byproduct and had a high content of condensed aromatic compounds. Chamber ovens were operated in Kohtla-Järve, Estonia from 1948 to 1987 [23]. 


\subsection{Tunnel oven}

In a tunnel oven the oil shale was moved through a long tunnel that has drying, retorting and extinguishing zones. The oil shale was placed in wagons that were then moved through the tunnel. The tunnel oven was heated on the outside using heavy oil, gas or flue gas obtained from burning finely ground oil shale. The feed for the retort itself was oil shale pieces with a size of $25-125 \mathrm{~mm}$. The retorting temperature in a tunnel oven reached $500{ }^{\circ} \mathrm{C}$. The retort was designed with oil production as the main objective, but a gas with a high heating value was also obtained $\left(33-38 \mathrm{MJ} / \mathrm{Nm}^{3}\right)$.

The tunnel oven retort was one of the earliest commercial retorts used in Estonia, with the first retort being built in 1925 . However, tunnel ovens cannot support the same production volumes that solid heat carrier and generator retorts can achieve, and have been out of use since 1975 [23].

\subsection{Rotating retort}

Rotating retorts consisted of a rotating metal cylinder housed in a brick chamber [30]. They were also known as Davidson retorts. The cylinder was heated externally using flue gas, and the retorting temperature was $500^{\circ} \mathrm{C}$. Heat for the retort was obtained by burning semicoke, which is the solid residue left after pyrolysis. The residence time of oil shale in the reactor was 8 hours, and a shale grain size $<25 \mathrm{~mm}$ could be used. One downside of the rotating retort was its low production rate (about 25 metric tons per day). Davidson rotating retorts were operated in Kohtla-Nõmme, Estonia from 1931 to 1961 [23].

\subsection{Fusion retort}

A fusion retort was a horizontal retort. It was heated externally, and the retorting temperature reached $540{ }^{\circ} \mathrm{C}$. It was capable of retorting small oil shale pieces [24]. It has also been described as a rotating retort [25]. A fusion retort was operated in Vanamõisa, Estonia from 1923 to 1931 [23].

\subsection{Generator}

In a generator retort the oil shale is heated in a vertical shaft $[27,28,31]$. It is also called a vertical retort, gas generator retort, or gas combustion retort, and is known as the Kiviter process. The earliest retort was called a Pintsch retort. Oil shale is fed into the top of the shaft and then descends through the retorting zone. The heat carrier is heated gases that are circulated through the system. The spent shale is collected at the bottom of the shaft. The retorting temperature reaches $700-860{ }^{\circ} \mathrm{C}$, and oil shale with a particle size of $25-125 \mathrm{~mm}$ is used. Generators were designed for oil production, and low calorific gas is a byproduct. The oil produced contains very few low boiling compounds, and the distillation curve shows that the oil is heavier than that of other retorting technologies. 
Additionally, these retorts produce phenolic water as a byproduct. The phenols in this water have generally been extracted and sold as fine chemicals, which continues to be a product line for VKG [32].

Generator retorts have been used since the very beginning of commercial shale oil production in Estonia, with the first retort being built in 1921 [23]. Generators are still currently used.

\subsection{Solid heat carrier}

The solid heat carrier method uses oil shale ash as the heat carrier. The solid residue from pyrolysis (semicoke) is burned, which yields the hot ash that is used as the heat carrier. Using the semicoke as the heat source gives the process a high efficiency. The retort uses finely ground oil shale $(<25 \mathrm{~mm})$, and the retorting temperature peaks at $500{ }^{\circ} \mathrm{C}$ [33]. This type of retort is used in the Galoter process. The Enefit140, Enefit280, and Petroter technologies also utilize solid heat carrier retorts [5-8].

The solid heat carrier retort was developed later than other retorts. The technology was first used commercially in 1963 [33], and now most shale oil is produced in Estonia in a solid heat carrier retort.

\subsection{Composition of kukersite shale oil}

During pyrolysis the organic matter in oil shale is converted into gas, oil, and a solid residue called semicoke. Currently, the oil is often further separated into three wide fractions in industry: shale gasoline, fuel oil, and heavy oil [33].

The lightest fraction, shale gasoline, is generally the portion of the shale oil that is distilled below $200{ }^{\circ} \mathrm{C}$. The composition of shale gasoline from different retorts has been reported in several different sources [34, 36, 40, 45, 47, 48] (summarized in the Appendix). From this data we can see that shale gasoline contains significant amounts of olefins. Due to the large amount of unsaturated hydrocarbons shale gasoline is unstable and over time undergoes polymerization reactions to form a resin like product that precipitates. Aromatic compounds, including phenolic compounds, are also present, but they are not as prevalent in the shale gasoline as they are in the fuel oil and heavy oil.

The higher boiling portion of kukersite shale oil consists largely of aromatic compounds, which are mostly phenolic compounds. However, these aromatic rings often have long aliphatic side chains attached to them as well [49]. These types of structures appear to be prevalent in kukersite kerogen, as can be seen in the proposed structure given by Lille et al. [9]. As part of this project, we used infrared spectroscopy to investigate the composition of the oil, including its heavier portions [50]. Based on the infrared spectra, the fuel oil contains some smaller aromatic compounds, including phenols and resorcinols, which do not have long aliphatic chains. These smaller compounds are distilled first, and the concentration of polar hydroxyl groups is highest in these mid-range 


\begin{tabular}{|c|c|c|c|c|c|c|c|c|c|c|c|c|}
\hline Кesse .ә૫эธ! & 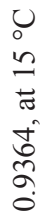 & $\stackrel{+}{\Delta}$ & $\begin{array}{l}0 \\
0 \\
0 \\
n \\
\pi \\
\pi \\
\infty \\
0 \\
0 \\
n\end{array}$ & 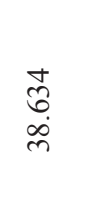 & $\frac{n}{n}$ & $\stackrel{\ominus}{V}$ & । & $\begin{array}{l}0 \\
0 \\
\infty \\
0 \\
0 \\
\infty \\
\infty\end{array}$ & । & I & $\hat{6}$ & \\
\hline 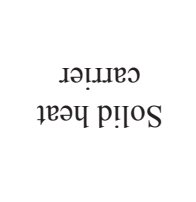 & $\frac{\infty}{0}$ & $\stackrel{\circ}{\stackrel{0}{\sim}}$ & 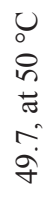 & $\begin{array}{l}\stackrel{0}{n} \\
\text { mे }\end{array}$ & $\widehat{\imath}$ & $\approx$ & 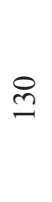 & 으 & ส & ले & $\vec{b}$ & $\begin{array}{l}\tilde{f} \\
\dot{J}\end{array}$ \\
\hline 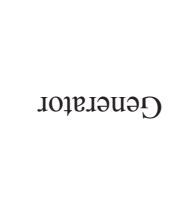 & $\begin{array}{l}\infty \\
\text { ò } \\
0\end{array}$ & ঐे & 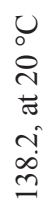 & mे & $\ddot{\imath}$ & ส̃ & $\stackrel{2}{2}$ & $N$ & $r$ & 9 & f & $\begin{array}{l}\text { J } \\
\tilde{n} \\
m \\
\dot{m}\end{array}$ \\
\hline uo!̣sn & 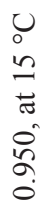 & 1 & $\begin{array}{l}0 \\
0 \\
0 \\
n \\
n \\
n \\
n \\
n\end{array}$ & 1 & 1 & $\bar{\sim}$ & 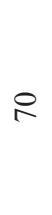 & $\infty$ & లి & $\mathscr{F}$ & 1 & $\stackrel{\mathscr{g}}{\dot{y}}$ \\
\hline 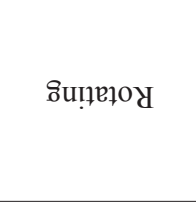 & aे & సి & 1 & $\begin{array}{l}n \\
\hat{\infty} \\
\dot{q} \\
\dot{q}\end{array}$ & 1 & \pm & $\approx$ & ิ & Әे & ร & ţ & $\begin{array}{l}\text { Tे } \\
\text { वे } \\
\text { f } \\
0 \\
0 \\
0 \\
0 \\
0\end{array}$ \\
\hline иəАо [əuนn $L$ & $\begin{array}{l}0 \\
2 \\
0\end{array}$ & $\tilde{n}$ & 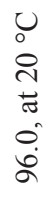 & $\stackrel{?}{\vec{\forall}}$ & $\stackrel{\overbrace{}}{\uparrow}$ & & $n$ & ป & ஓ & ले & $\stackrel{\circ}{n}$ & $\begin{array}{l}\text { సे } \\
\text { bे } \\
\text { d }\end{array}$ \\
\hline шәАо .әфшеЧว & $\stackrel{8}{\leftrightarrows}$ & $\stackrel{\mathfrak{I}}{\sim}$ & 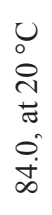 & $\stackrel{\substack{\infty \\
m \\
m}}{ }$ & I & $\infty$ & $\stackrel{n}{n}$ & 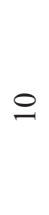 & $\stackrel{\infty}{\sim}$ & 웅 & ชื & $\begin{array}{l}n \\
m \\
\stackrel{n}{n}\end{array}$ \\
\hline & 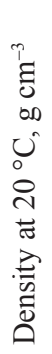 & 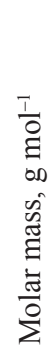 & 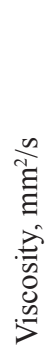 & 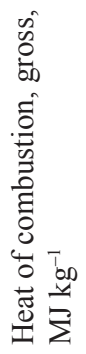 & $\begin{array}{l}0 \\
\circ \\
. \mathfrak{\Xi} \\
0 \\
0 \\
0 \\
0\end{array}$ & 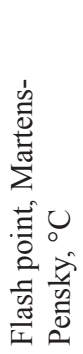 & 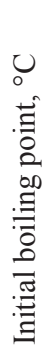 & 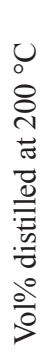 & $\begin{array}{l}\text { O } \\
\circ \\
\stackrel{\sim}{\sim}\end{array}$ & $\begin{array}{l}0 \\
0 \\
8 \\
\text { O }\end{array}$ & $\begin{array}{l}\text { O } \\
\text { on } \\
n\end{array}$ & 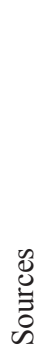 \\
\hline
\end{tabular}


fractions (distilling at about $300-350{ }^{\circ} \mathrm{C}$ ). The heavier fractions appearing later in the distillation contain aromatic and phenolic compounds with long straight hydrocarbon chains [49].

\section{Methods}

\subsection{Sample preparation}

The shale oil samples used for this research were obtained from Eesti Energia's Narva Oil Plant (Auvere, Estonia). Most of the samples were taken from the Enefit 140 plants in 2013 and 2015. The Enefit140 plants have also been called TSK-3000 or UTT-3000 in the past. One fuel oil sample was also taken from the newer Enefit280 plant [33]. The properties of these industrial samples are presented in Table 2.

The gasoline and fuel oil samples were then separated into fractions with narrow boiling ranges using distillation. Four different types of distillation were performed:

- Batch distillation (also called Engler distillation, ASTM D86 [51]). Some of these batch distillations used more than $100 \mathrm{~mL}$ of oil, so they did not strictly follow the ASTM D86 standard.

- Vacuum batch distillation, where the distillation began at atmospheric pressure like a normal batch distillation, and then was transitioned to vacuum pressures (usually in the range of 0.3 to $30 \mathrm{mbar}$ ) to allow distillation of the heavier fractions without decomposition.

- Column distillation based on the ASTM D2892 standard [52]. For the shale gasoline a Vigreux column was used that had 4.2 theoretical plates, and the reflux ratio used was $6: 1$. For the fuel oil a packed column was used (24 theoretical plates, reflux ratio of $6: 1$ ). The column diameter was $3.5 \mathrm{~cm}$ and it was packed to a height of $0.86 \mathrm{~m}$. The packing for the column was wire spirals that were $3 \mathrm{~mm}$ long and $2.5 \mathrm{~mm}$ in diameter, and the wire had a diameter of $0.24 \mathrm{~mm}$ [53].

- Double batch distillation, which involved performing an initial batch distillation to recover the lightest portion of the fuel oil (or actually four separate batch distillations to get enough material), and then performing a second batch distillation on that lighter oil. This was done to more thoroughly study the lightest portion of the fuel oil.

A summary of the distillations performed is given in Table 3. When not being analyzed, the samples were stored in closed containers in a refrigerator at $+5{ }^{\circ} \mathrm{C}$. 


\begin{tabular}{|c|c|c|c|c|c|c|c|c|c|c|c|c|}
\hline 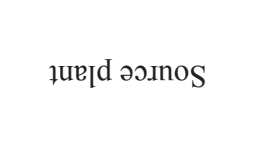 & & 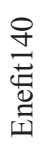 & 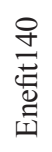 & 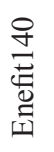 & 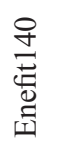 & 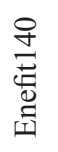 & 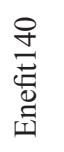 & $\begin{array}{l}\stackrel{P}{+} \\
\underset{D}{ \pm} \\
\text { 辛 }\end{array}$ & 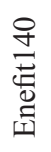 & 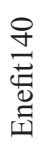 & 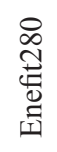 & $\begin{array}{l}\stackrel{+}{+} \\
\text { 苞 } \\
\text { 壱 }\end{array}$ \\
\hline ұшәұшоэ $\mathrm{HO}$ & $\begin{array}{l}\text { oे } \\
\text { के } \\
\text { घे }\end{array}$ & & & & 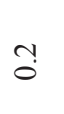 & & mis & $\begin{array}{l}n \\
i n\end{array}$ & $\ddot{n}$ & ir & $\underset{\dot{m}}{\dot{m}}$ & $n$ \\
\hline ұนวฺนоว นәธิо..р $\kappa_{\mathrm{H}}$ & $\begin{array}{l}\text { बें } \\
\text { जे } \\
\text { घे }\end{array}$ & $\stackrel{n}{n}$ & & & & $\vec{\alpha}$ & $\vec{\alpha}$ & $\stackrel{\sim}{\sim}$ & n̊? & $\underset{\sigma}{J}$ & $\stackrel{\sim}{a}$ & \\
\hline 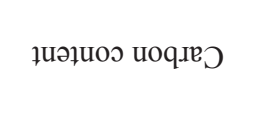 & $\begin{array}{l}\text { बें } \\
\text { जे } \\
\text { घै }\end{array}$ & $\stackrel{+}{+}$ & & & & $\frac{\sim}{\infty}$ & $\frac{n}{\infty}$ & $\frac{\dot{\infty}}{\infty}$ & & $\frac{n}{\infty}$ & $\vec{\infty}$ & \\
\hline 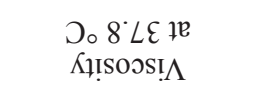 & $\begin{array}{l}\infty \\
\dot{\tilde{\sigma}} \\
\dot{\Xi}\end{array}$ & & & & & $\ddot{q}$ & $\bar{\nabla}$ & & ¿ & & & \\
\hline SSEU .IE[OW & $\begin{array}{l}\frac{T}{D} \\
\stackrel{g}{G} \\
0 \infty\end{array}$ & & & & & & & & & & & $\overrightarrow{\widetilde{N}}$ \\
\hline 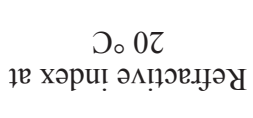 & & & & & & $\stackrel{n}{n}$ & in & त్ర & $\begin{array}{l}\stackrel{8}{\circ} \\
\stackrel{n}{-}\end{array}$ & 离 & & \\
\hline 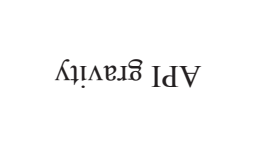 & & $\begin{array}{l}n \\
0 \\
0 \\
\dot{q}\end{array}$ & $\begin{array}{l}\stackrel{+}{\pi} \\
\text { ì } \\
\dot{\sigma}\end{array}$ & $\begin{array}{l}\overrightarrow{0} \\
n \\
0 \\
\dot{o}\end{array}$ & 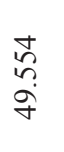 & $\begin{array}{l}\stackrel{\infty}{\infty} \\
\stackrel{m}{m}\end{array}$ & $\underset{\substack{\infty \\
+}}{+}$ & $\begin{array}{l}n \\
\tilde{n} \\
n\end{array}$ & $\begin{array}{l}\vec{\Xi} \\
\dot{+}\end{array}$ & 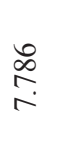 & $\vec{b}$ & $\underset{\hat{\alpha}}{\infty}$ \\
\hline 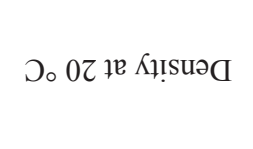 & $\begin{array}{l}\tilde{B} \\
\Xi \\
\underline{90}\end{array}$ & $\begin{array}{l}\stackrel{\infty}{\infty} \\
\stackrel{\infty}{\infty}\end{array}$ & 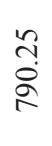 & $\begin{array}{l}0 \\
\text { n̊ } \\
\stackrel{2}{2}\end{array}$ & $\begin{array}{l}+ \\
\stackrel{2}{0} \\
\stackrel{2}{2}\end{array}$ & 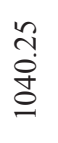 & 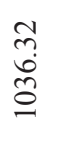 & $\begin{array}{l}\hat{\sigma} \\
\stackrel{\sigma}{\sigma}\end{array}$ & $\begin{array}{l}\text { ळे } \\
\text { ले } \\
\text { के }\end{array}$ & $\stackrel{?}{\stackrel{\Xi}{\Xi}}$ & $\begin{array}{l}\stackrel{\infty}{i} \\
\stackrel{\delta}{\sigma}\end{array}$ & $\begin{array}{l}\text { बे } \\
\text { है }\end{array}$ \\
\hline 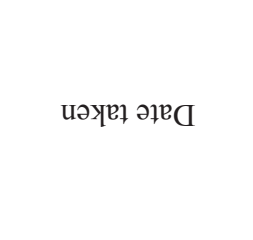 & & 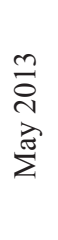 & 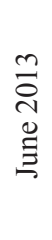 & $\begin{array}{l}\stackrel{m}{\circ} \\
\underset{\sim}{0} \\
\stackrel{000}{\Xi}\end{array}$ & 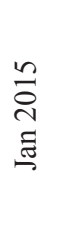 & $\begin{array}{l}m \\
\stackrel{\sim}{*} \\
\tilde{U} \\
0 \\
\tilde{\sim}\end{array}$ & 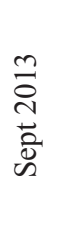 & 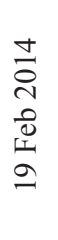 & 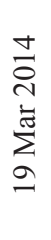 & 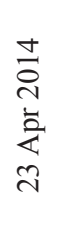 & 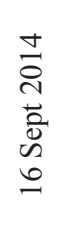 & 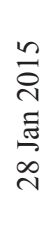 \\
\hline .әџ!ฺนәрі & & $\begin{array}{l}n \\
n \\
0 \\
0 \\
3\end{array}$ & $\begin{array}{l}m \\
0 \\
0 \\
0 \\
3\end{array}$ & $\begin{array}{l}n \\
\infty \\
\infty \\
0 \\
0 \\
j\end{array}$ & 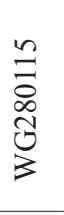 & 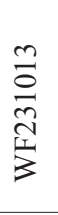 & $\begin{array}{l}\frac{m}{2} \\
8 \\
1 \\
3\end{array}$ & 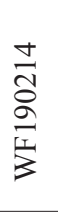 & $\begin{array}{l}\frac{ \pm}{\infty} \\
\frac{\delta}{\circ} \\
\frac{1}{3}\end{array}$ & 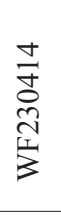 & $\begin{array}{l}\frac{\nabla}{\sigma} \\
\stackrel{0}{0} \\
\frac{1}{3}\end{array}$ & 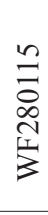 \\
\hline
\end{tabular}


Table 3. Distillations performed

\begin{tabular}{|c|c|c|c|}
\hline Identifier & Date & Type & Initial sample used \\
\hline GR240513 & 24 May 2013 & Column distillation & WG0513 \\
GR060613 & 6 Jun 2013 & Column distillation & WG0613 \\
GD071013 & 7 Oct 2013 & Batch distillation & WG280813 \\
GD020215 & 2 Feb 2015 & Batch distillation & WG280115 \\
FD040214 & 4 Feb 2014 & Batch distillation & WF231013 \\
FD070214 & 7 Feb 2014 & Batch distillation & WF231013 \\
FD070514 & 7 May 2014 & Batch distillation & WF230414 \\
FD111113 & 11 Nov 2013 & Batch distillation & WF231013 \\
FD151013 & 15 Oct 2013 & Batch distillation & WF0913 \\
FD190115 & 19 Jan 2015 & Batch distillation & WF160914 \\
FD260214 & 26 Feb 2014 & Batch distillation & WF190214 \\
FD260314 & 26 Mar 2014 & Batch distillation & WF190314 \\
FN110214 & 11 Feb 2014 & Double batch distillation & WF231013 \\
FR0614 & June 2014 & Column distillation & WF230414 \\
FR210115 & 21 Jan 2015 & Column distillation & WF160914 \\
FV030414 & 3 Apr 2014 & Vacuum batch distillation & WF190314 \\
FV070415 & 7 Apr 2015 & Vacuum batch distillation & WF280115 \\
FV081113 & 8 Nov 2013 & Vacuum batch distillation & WF231013 \\
FV130315 & 13 Mar 2015 & Vacuum batch distillation & WF280115 \\
FV271114 & 27 Nov 2014 & Vacuum batch distillation & WF160914 \\
\hline HV13 & Vacuum batch distillation & Enefit140 heavy oil \\
\hline
\end{tabular}

A few things should be noted about some of the fractions. The heavy oil sample had been mixed with shale gasoline at the plant. This is done to reduce the viscosity of the heavy oil and make it easier to transport. Therefore, the first three fractions from this distillation contained mostly gasoline, and for that reason these samples were not studied or data included here. Also, temperatures as high as $400{ }^{\circ} \mathrm{C}$ were reached at the end of some of the vacuum 
distillations because the heaviest portion of the fuel oil had a high vapor pressure, and decomposition was observed when recovering some of these heaviest fractions.

Each oil sample measured has been given an identifier, which generally consists of the identifier for the distillation followed by a dash and then the fraction number. For instance, the sixth fraction from the May 2013 gasoline distillation has the identifier GR240513-6. For the residue from a distillation an $\mathrm{R}$ is used at the end instead of a number. The whole fractions that were the starting material for the distillations were given identifiers starting with a letter W.

We also measured some properties of selected crude shale oil samples, and these properties are given in Table 4. Three of the crude shale oils were produced in our laboratory using a Fischer retort [54]. For one of these Fischer experiments a concentrated kerogen sample was used from which much of the mineral matter in the oil shale had been removed. One sample was mixed to resemble crude oil from the Enefit140 process (also called the Galoter process). Because the oil vapor from pyrolysis is sent directly to the distillation column, it is not possible to recover actual crude oil from the process. So to approximate crude oil from the Enefit 140 process, we mixed the three fractions (gasoline, fuel oil, and heavy oil) in the same mass ratio as given in the plant's design documents (20:60:20) [19].

Table 4. Properties of crude kukersite shale oil samples

\begin{tabular}{|c|c|c|c|c|c|c|c|c|}
\hline 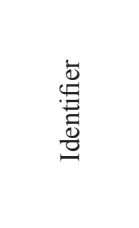 & 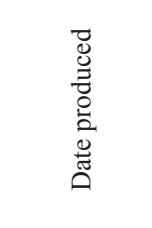 & 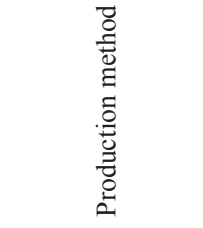 & 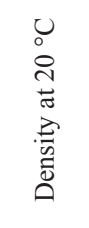 & 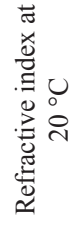 & 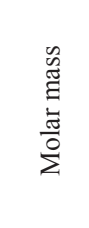 & 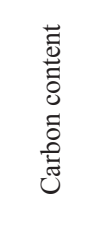 & 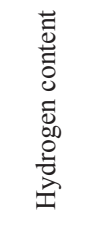 & 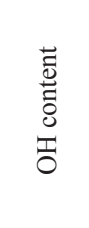 \\
\hline & & & $\mathrm{kg} \mathrm{m}^{-3}$ & & $\mathrm{~g} \mathrm{~mol}^{-1}$ & $\operatorname{mass} \%$ & mass $\%$ & mass $\%$ \\
\hline CF260614 & 26 June 2014 & Fischer retort & 943.64 & 1.521 & & 82.5 & 10.51 & 3.0 \\
\hline CF300614 & 30 June 2014 & Fischer retort & 951.99 & 1.527 & & 82.8 & 10.48 & 3.1 \\
\hline CFK140115 & 14 Jan 2015 & $\begin{array}{l}\text { Fischer retort of } \\
\text { only kerogen }\end{array}$ & 952.24 & & & 82.7 & 10.31 & \\
\hline CG0614 & June 2014 & $\begin{array}{c}\text { Mixture } \\
\text { resembling crude } \\
\text { Enefit } 140 \text { oil }\end{array}$ & 979.90 & 1.546 & 236 & 82.3 & 9.52 & 4.1 \\
\hline
\end{tabular}




\subsection{Preparing phenol rich and dephenolated samples}

The phenolic compounds were extracted from the shale oil using a $10 \%$ aqueous $\mathrm{NaOH}$ solution. The procedure is essentially the same as that used by Kogerman [43], and has also been described by Baird et al. in an earlier article [49]. The oil was generally mixed with benzene at the start, and then the $\mathrm{NaOH}$ solution was added. The two phases were thoroughly mixed in the separation funnel, and then the mixture was left standing to allow the phases to separate. The denser aqueous phase contained phenols, and it was then removed from the bottom. Another portion of $\mathrm{NaOH}$ was then added and the process was repeated about 4 more times. At the end distilled water was added to remove any $\mathrm{NaOH}$ left in the oil.

With the phenolic compounds removed, the second step was to evaporate the benzene and any remaining water from the dephenolated oil. This was done in a rotary evaporator at about $80{ }^{\circ} \mathrm{C}$ with a vacuum of about 25 mbar. The result was oil with most of the phenols removed, i.e. dephenolated oil.

The third step was to extract the phenolic compounds from the aqueous phase. The solution was acidified to a $\mathrm{pH}$ of about 3 using sulfuric acid, which reprotonates the hydroxyl groups and makes it more likely that the phenols will end up in the organic phase. Then diethyl ether was added to extract the phenols. After thorough mixing, the ether and water phases separated and the ether phase was removed from the top using a water jet pump connected to a collection vessel.

The final step was to evaporate the ether and any remaining water. The rotary evaporator was again used for this. Initially, the rotary evaporator was kept at atmospheric pressure and a lower temperature of $40{ }^{\circ} \mathrm{C}$. This was done because diethyl ether has a high vapor pressure. Then the evaporator was heated to about $80^{\circ} \mathrm{C}$, and finally, a vacuum of about 25 mbar was applied to remove any water that might have remained in the sample.

The properties of the dephenolated and phenol rich shale fuel oil samples are given in Table 5. Note that some phenolic compounds still remained in the dephenolated oil, so the dephenolated oil does have significantly fewer phenolic compounds, but is not completely free of them. For a separate project Baird et al. [55, 56] also prepared dephenolated oil, and additional data on dephenolated shale fuel oil can be obtained from those articles.

The dephenolated and phenol rich fuel oil was also separated into narrow boiling fractions to better investigate the properties of the oil. Usually this was done by distilling the dephenolated and phenol rich samples; however, one set of extractions was performed on narrow fractions that had already been distilled. Table 6 gives an overview of the distillations performed and the narrow dephenolated and phenol rich fractions obtained. 


\begin{tabular}{|c|c|c|c|c|c|c|c|c|c|}
\hline ә¡dures әว.ınos & & $\begin{array}{l}\frac{m}{0} \\
\stackrel{2}{2} \\
\stackrel{1}{3}\end{array}$ & $\begin{array}{l}\frac{\Delta}{2} \\
\frac{0}{0} \\
\frac{1}{3}\end{array}$ & 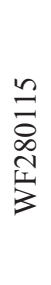 & \begin{tabular}{l}
$\stackrel{n}{a}$ \\
$\overline{0}$ \\
$\stackrel{\infty}{0}$ \\
N \\
\multirow{3}{*}{}
\end{tabular} & 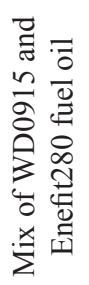 & $\begin{array}{l}\frac{m}{0} \\
\stackrel{0}{3} \\
\stackrel{1}{3}\end{array}$ & 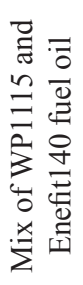 & 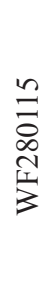 \\
\hline ұుəૈ๘о0 HO & 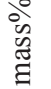 & $\ddot{n}$ & $\tilde{0}$ & 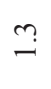 & $\stackrel{\text { Iִ }}{-}$ & $\underset{\sim}{\sim}$ & $\overrightarrow{0}$ & $\overbrace{0}^{\infty}$ & $\stackrel{?}{\infty}$ \\
\hline 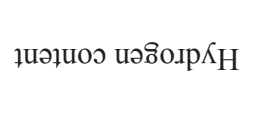 & $\begin{array}{l}\text { oे } \\
\text { जै } \\
\text { छै }\end{array}$ & $\begin{array}{l}\Delta \\
\infty\end{array}$ & & & & & $\underset{r}{r}$ & & \\
\hline 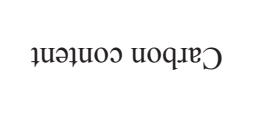 & 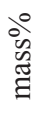 & $\stackrel{\infty}{\infty}$ & & & & & $\stackrel{?}{\stackrel{2}{r}}$ & & \\
\hline Sseש .ı[OW & $\begin{array}{l}\frac{T}{\partial} \\
\Xi \\
\text { b }\end{array}$ & & & & & $\overrightarrow{\mathrm{N}}$ & & $\stackrel{尺}{\curvearrowright}$ & \\
\hline 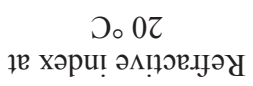 & & $\stackrel{\substack{\infty\\
}}{i n}$ & & & & $\stackrel{n}{n}$ & $\overbrace{0}^{\infty}$ & î̊ & $\stackrel{n}{n}$ \\
\hline 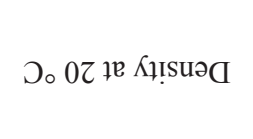 & 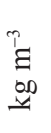 & $\begin{array}{l}\vec{\infty} \\
\infty \\
\infty \\
0 \\
0\end{array}$ & $\frac{8}{\frac{8}{0}}$ & & & 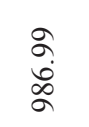 & $\begin{array}{l}\text { त̂ } \\
\text { లె } \\
ٍ \\
=\end{array}$ & $\begin{array}{l}\text { in } \\
\text { in } \\
\text { o }\end{array}$ & $\begin{array}{l}+ \\
+ \\
\dot{J} \\
\stackrel{0}{0}\end{array}$ \\
\hline$\partial \mathrm{d} \kappa_{\mathrm{L}}$ & & 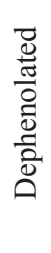 & 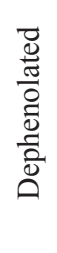 & 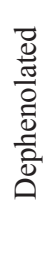 & 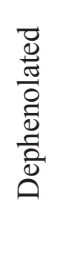 & $\begin{array}{l}\vec{d} \\
\frac{0}{0} \\
0 \\
\overline{0} \\
\overline{0} \\
0\end{array}$ & $\begin{array}{l}\frac{0}{0} \\
\overline{0} \\
\frac{0}{0} \\
\frac{0}{2}\end{array}$ & $\begin{array}{l}\frac{\overrightarrow{0}}{0} \\
\overline{0} \\
\overline{0} \\
\frac{0}{2}\end{array}$ & $\begin{array}{l}\frac{\tilde{D}}{0} \\
\bar{O} \\
\overline{0} \\
\frac{D}{2}\end{array}$ \\
\hline เәџ!ุนәрі & & 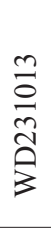 & $\frac{n}{\infty}$ & 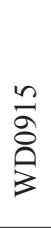 & $\frac{n}{\frac{n}{6}}$ & 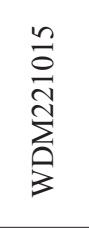 & $\begin{array}{l}m \\
0 \\
\tilde{o} \\
\hat{n} \\
\hat{z}\end{array}$ & 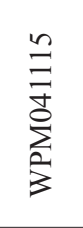 & $\frac{n}{\equiv}$ \\
\hline
\end{tabular}




\begin{tabular}{|c|c|c|c|c|c|c|c|}
\hline 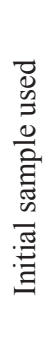 & 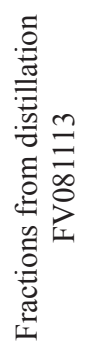 & $\frac{n}{\grave{8}}$ & 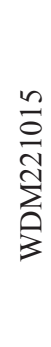 & $\frac{n}{\frac{n}{0}}$ & 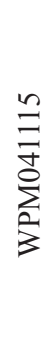 & 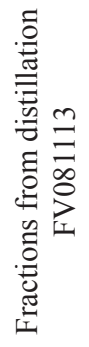 & $\frac{n}{\equiv}$ \\
\hline $\begin{array}{l}\text { D } \\
\text { 苞 } \\
\sum_{\Sigma}^{0}\end{array}$ & 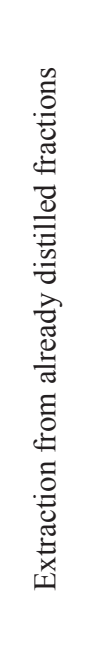 & 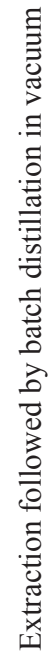 & 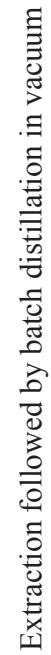 & 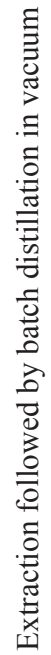 & 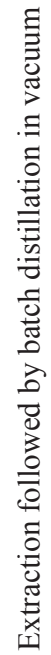 & 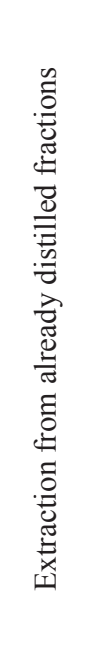 & 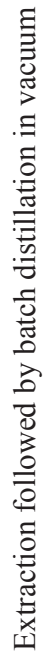 \\
\hline$\stackrel{\tilde{\Xi}}{\tilde{\Xi}}$ & 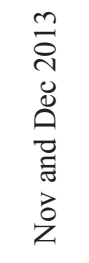 & $\begin{array}{l}n \\
\stackrel{n}{0} \\
\stackrel{0}{4}\end{array}$ & $\begin{array}{l}n \\
\stackrel{n}{0} \\
\stackrel{\sim}{0} \\
0\end{array}$ & $\begin{array}{l}n \\
\stackrel{n}{0} \\
\tilde{d} \\
\tilde{D}\end{array}$ & 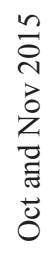 & $\begin{array}{l}m \\
\stackrel{n}{0} \\
0 \\
0 \\
0 \\
\tilde{D} \\
\tilde{\sigma} \\
\overrightarrow{0} \\
z\end{array}$ & $\begin{array}{l}n \\
\text { in } \\
\text { a } \\
z\end{array}$ \\
\hline 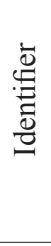 & $\begin{array}{l}\stackrel{m}{\equiv} \\
\overrightarrow{0} \\
\stackrel{0}{2}\end{array}$ & $\begin{array}{l}n \\
\dot{8} \\
0 \\
0 \\
0\end{array}$ & $\begin{array}{l}n \\
0 \\
0 \\
\text { N } \\
\text { 方 }\end{array}$ & $\begin{array}{l}n \\
\stackrel{n}{a} \\
\infty \\
0 \\
0\end{array}$ & $\begin{array}{l}n \\
\exists \\
\vec{J} \\
2 \\
2\end{array}$ & $\begin{array}{l}\stackrel{m}{\equiv} \\
\equiv \\
0 \\
2\end{array}$ & 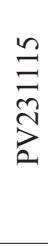 \\
\hline
\end{tabular}


The first fraction from distillation DV221015 contained a significant amount of benzene, which was used as part of the extraction process. The benzene was identified from the infrared spectrum of the sample. For this reason that sample is not included in the data.

\subsection{Molecular weight}

Cryoscopy and vapor pressure osmometry were used to measure number average molecular weights (MW). For cryoscopy, the device used was built in house and the method is described in the ASTM D2224 standard [57]. The solvent used was benzene. More information about the device and procedure were given by Järvik and Oja [19]. Almost all of the molecular weights were measured using cryoscopy.

Vapor pressure osmometry was also used with a few of the samples. Vapor pressure osmometry was performed using a Knauer K-7000 device (Wissenschaftliche Gerätebau Dr. Ing. Herbert KNAUER GmbH), as was described by Järvik and Oja [19]. Benzene was used as the solvent, and for calibration benzyl solutions were used.

The procedure for estimating the uncertainty of these methods was described in detail by Järvik and Oja [19], and it was based on data from tests with pure compounds. The calculated relative expanded uncertainty (at the $95 \%$ level) was between \pm 6 and $\pm 7 \%$, which means that on average the absolute standard uncertainty was $7 \mathrm{~g} / \mathrm{mol}$ (absolute expanded uncertainty of $14 \mathrm{~g} / \mathrm{mol}$ at the $95 \%$ level).

\subsection{Density}

To measure the density (den) an Anton Paar DMA 5000M oscillating tube density meter was used. For pure compounds this device is estimated to have an expanded uncertainty of $0.00005 \mathrm{~g} \mathrm{~cm}^{-3}$, but for oils the uncertainty is higher due to difficulties in measuring these complex mixtures. To estimate the uncertainty, we performed repeat measurements with oil samples, and from these the standard uncertainty was roughly estimated to be $0.00015 \mathrm{~g} \mathrm{~cm}^{-3}$. Densities reported here were measured at $20^{\circ} \mathrm{C}$.

\subsection{Refractive index}

For refractive index an Abbemat HT (Anton Paar) refractometer was used, which performs measurements at a wavelength of $589.592 \mathrm{~nm}$ (i.e. a sodium D line, $\mathrm{n}_{\mathrm{D}}$ ). The values reported here were measured at $20^{\circ} \mathrm{C}$. Although the device measures quite accurately (measurements with water were always within 0.00002 of the reference value), oil samples are more difficult to measure, which leads to a higher uncertainty. To estimate this uncertainty we made repeat measurements with oil samples. The standard uncertainty was estimated to be 0.0011 (expanded uncertainty of 0.0021 at the $95 \%$ level). 


\subsection{Elemental composition}

A CE-440 elemental analyzer (Exeter Analytical Inc.) was used to measure the hydrogen and carbon contents of the gasoline fractions. The standard uncertainty of hydrogen content was $0.084 \mathrm{wt} \%$ (estimated expanded uncertainty of $0.17 \mathrm{wt} \%$ at the $95 \%$ level), and the standard uncertainty of the carbon content was $0.36 \mathrm{wt} \%$ (estimated expanded uncertainty of $0.72 \mathrm{wt} \%$ at the $95 \%$ level). These uncertainties were estimated based on measurements performed using known organic compounds (acetanilide, cyclohexanone, resorcinol, pyrene).

\subsection{Boiling point estimation}

Because batch distillation was the main method used, the average boiling points of the samples had to be measured using another method. A distillation with a column can directly provide true boiling point data when a sufficient number of plates is used, but simple batch distillation does not [53]. To measure the average boiling points we used a method, developed in our lab, which is based on thermogravimetric analysis [53]. In short, a small amount of the sample was placed in a pan with a lid, which was then heated in the thermogravimetric analyzer. The lid had a small pinhole in it, and as the sample vaporized, it would leave the pan through the pinhole. From this mass loss data the average boiling point can be calculated.

The uncertainty of this method was calculated based on the fractions obtained using the Vigreux column according to ASTM D2892 [52], so for these fractions the boiling points were known. The standard uncertainty of the method was calculated to be $2.1^{\circ} \mathrm{C}$ (expanded uncertainty of $4.3{ }^{\circ} \mathrm{C}$ at the $95 \%$ level).

The heaviest fractions had boiling points above $400{ }^{\circ} \mathrm{C}$. At these high temperatures the samples started to decompose in TGA when we attempted to measure the average boiling point [58]. For this reason, we did not include any average boiling points from the TGA method that were above $410{ }^{\circ} \mathrm{C}$.

\subsection{Hydroxyl content}

Kukersite shale oil contains significant amounts of phenolic compounds. For fractions from one of the distillations, we measured the hydroxyl content to understand how much of these compounds is present in the shale gasoline.

The hydroxyl content was measured based on the infrared spectra of the samples. A machine learning model, which had been trained earlier $[49,50]$, was used to calculate the hydroxyl content from the infrared spectrum. This machine learning model had a root mean squared error of 0.35 mass $\%$.

\subsection{Regressing correlation coefficients}

We developed correlations to calculate some shale oil properties from others 
that are commonly measured or could be easily measured. The basic form of these correlations is shown in Equation (see Section 4.3). It is similar to the equation given by Riazi [59] and Riazi and Daubert [60], but we added an additional coefficient that functions as an offset, which allows the correlation to start from a base value. We found this allowed the equation to achieve a better accuracy.

The constants for each correlation were fit to the experimental data we had measured for narrow shale oil fractions. Optimization was performed using the differential evolution optimizer [61] included in the Scipy package for Python [62]. As the objective function we used the least trimmed squares estimator with a cutoff set at the 95 th percentile [63]. This estimator was chosen because it is robust to outliers.

\section{Results and discussion}

\subsection{Properties of narrow fractions}

More than 350 samples were measured as part of this project, and therefore, there is too much data to reasonably include here in table format. Instead, the data has been placed in a scientific repository (Open Science Framework) from which it can be accessed (https://osf.io/fqjhd/).

The true boiling point curves obtained from the distillation fractions are presented in Figure 1. Note that these temperatures are not the distillation temperatures, rather these represent true boiling points that were calculated using the TGA method (see Section 3.7 and [53] for details). Because most distillations were batch distillations, true boiling point data could not be calculated directly from the distillation temperatures.
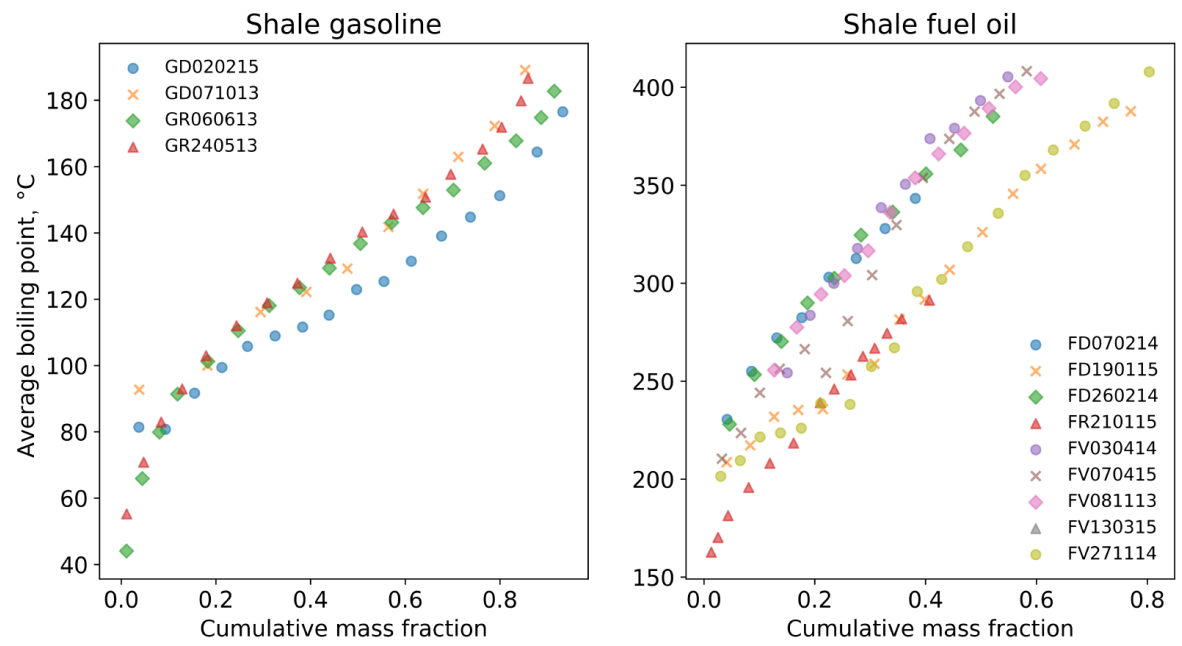

Fig. 1. True boiling point curves of the shale gasoline and shale fuel oil samples. 
The gasoline sample from 2015 had a lower boiling curve than the three samples from 2013. As mentioned, it is natural for the properties of the shale oil to vary due to variation in the oil shale used and differences in the plant's operation. Also, the boiling points for the first fractions from the batch distillations (GD071013 and GD020215) were likely overestimated. These fractions had boiling point distributions that were probably too wide, which can affect the TGA method [53].

With the shale fuel oil samples the true boiling point curves fall along two separate curves. The three distillations that gave lower boiling points used the same initial sample (WF160914), and unlike the other samples this one was from the newer Enefit 280 plant. This highlights how the composition and properties of shale oil can change depending on the pyrolysis conditions and processing method. Similar differences can also be seen by comparing the literature data for the properties of oil from different retorts given in Table 1.

For the lighter fractions, the density, refractive index, and average boiling point all increase essentially linearly along with the average molar mass of the fraction (see Fig. 2). For fractions above about $200 \mathrm{~g} \mathrm{~mol}^{-1}$, the density levels off at about $1050 \mathrm{~kg} \mathrm{~m}^{-3}$, and the refractive index levels off in a similar manner. These heavier fractions appear to have similar compositions: the

(a)

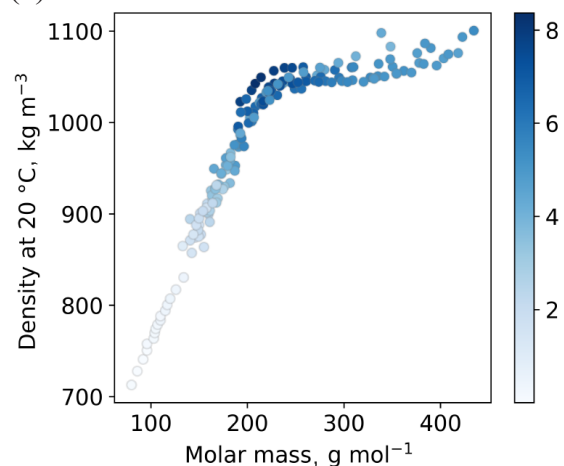

(c)

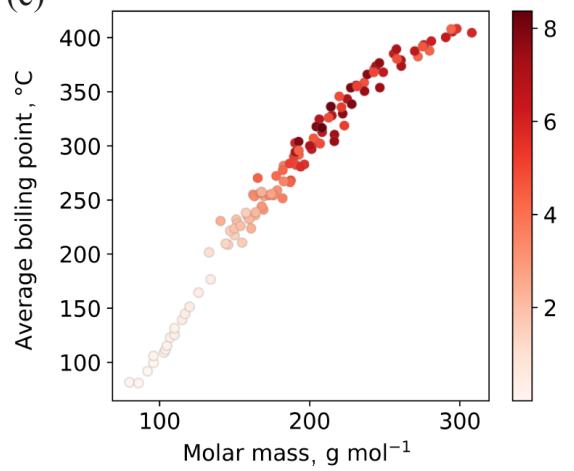

(b)

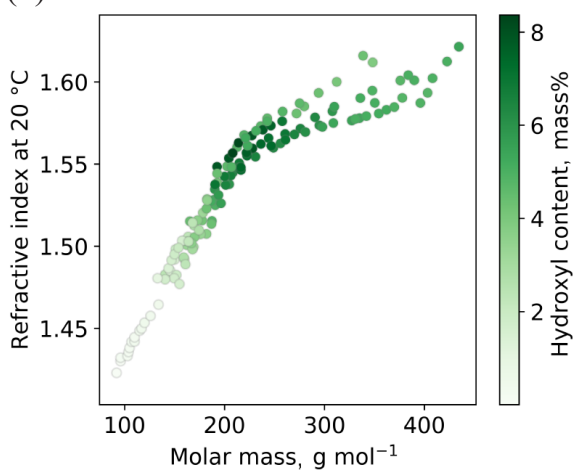

(d)

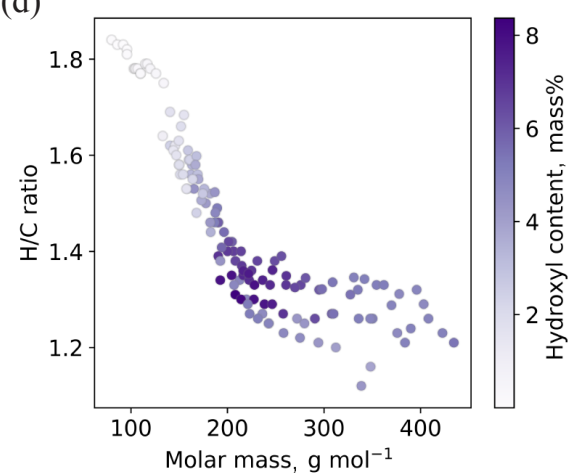

Fig. 2. Basic properties of the fractions as a function of molar mass. 
hydrogen-carbon ratio is essentially constant at around 1.3. Also, the hydroxyl group content decreases somewhat from the high concentrations in the middle fractions, reaching a value of around $4-5$ mass $\%$ in the heaviest fractions. This similarity in composition likely accounts for the similar density and refractive index values of these fractions.

\subsection{Influence of phenolic compounds}

Phenols are one of the main classes of compounds in kukersite shale oil, and the concentration of phenolic compounds can differ depending on the way the shale oil is produced and processed. To understand the impact of phenolic compounds on the properties of the oil, and also to enable our models to extrapolate better, we produced oil samples that were rich in phenols and some that had fewer phenols (dephenolated samples). The properties of these narrow fractions can be found from the data file in the OSF project page (https://osf.io/fqjhd/).

The way in which the phenolic compounds affect the properties can be better seen when including these phenol rich and dephenolated samples in the analysis (see Fig. 3). The difference is especially pronounced for density,

(a)

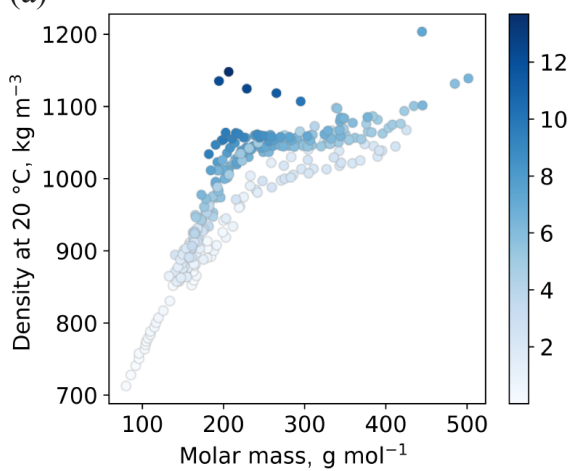

(c)

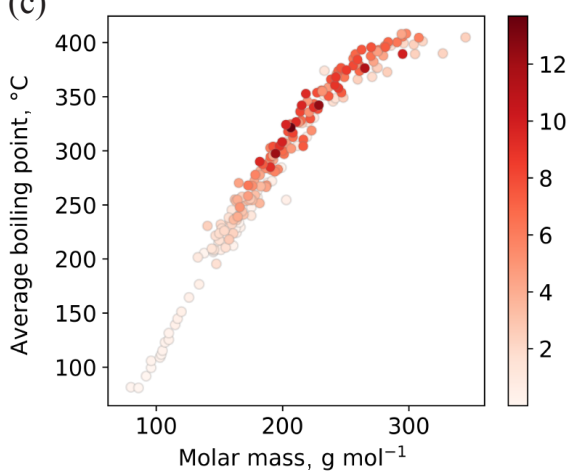

(b)

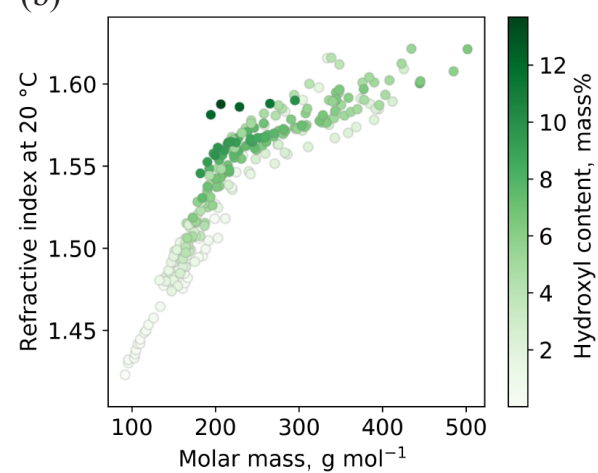

(d)

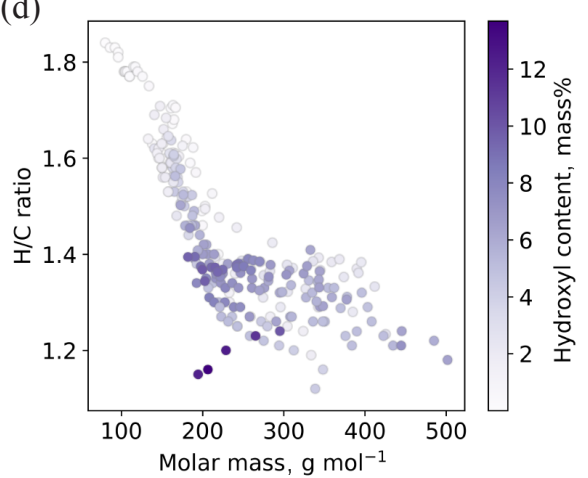

Fig. 3. Properties of all the narrow fractions as a function of molar mass and hydroxyl content. 
for which it is clear that samples with more phenolic compounds have higher densities. The refractive index also tends to be higher when there are more phenolic compounds. For the average boiling point, though, it is not so clear whether the impact of additional hydroxyl groups is high or not.

\subsection{Correlations between basic properties}

Generally, the molecular weight and hydroxyl group content are not measured in industry. Instead, properties like the distillation curve and density are usually measured. Therefore, we provide some correlations to convert between different combinations of basic properties (Equation). This enables more information about a kukersite shale oil to be obtained from properties that are already available:

$$
\theta=A \exp \left(B \theta_{1}+C \theta_{2}+D \theta_{1} \theta_{2}\right) \theta_{1}^{E} \theta_{2}^{F}+G,
$$

where $\theta$ is the property to be predicted, $\theta_{1}$ and $\theta_{2}$ are the two input parameters, and $A$ through $G$ are constants. Table 7 gives an overview of the correlations available, and the constants for each correlation are given both in the Appendix and on the OSF project page (https://osf.io/tvnmk/).

Table 7. Overview of correlations for calculating a property of a narrow kukersite shale oil fraction from two other known properties*

\begin{tabular}{|l|c|c|c|c|c|c|c|}
\hline $\begin{array}{l}\text { Predicted } \\
\text { property }\end{array}$ & Unit & Input 1 & Range & Input 2 & Range & AAD** & ARD*** \\
\hline $\mathrm{M}$ & $\mathrm{g} \mathrm{mol}^{-1}$ & $\mathrm{~T}_{\mathrm{b}}$ & $317-682$ & $\rho$ & $0.691-1.148$ & 5.9 & $3.1 \%$ \\
$\mathrm{M}$ & $\mathrm{g} \mathrm{\textrm {mol } ^ { - 1 }}$ & $\mathrm{T}_{\mathrm{b}}$ & $317-682$ & $\mathrm{RI}$ & $1.395-1.593$ & 6.2 & $3.1 \%$ \\
$\mathrm{OH}$ & $\mathrm{mass} \%$ & $\mathrm{~T}_{\mathrm{b}}$ & $353-682$ & $\rho$ & $0.712-1.148$ & 0.7 & - \\
$\mathrm{OH}$ & $\mathrm{mass}^{2}$ & $\mathrm{~T}_{\mathrm{b}}$ & $364-682$ & $\mathrm{RI}$ & $1.422-1.593$ & 1.4 & - \\
$\rho$ & $\mathrm{g} \mathrm{cm}^{-3}$ & $\mathrm{~T}_{\mathrm{b}}$ & $317-682$ & $\mathrm{RI}$ & $1.395-1.593$ & 0.0096 & $1.0 \%$ \\
$\mathrm{M}$ & $\mathrm{g} \mathrm{mol}^{-1}$ & $\rho$ & $0.691-1.148$ & $\mathrm{RI}$ & $1.395-1.621$ & 17.5 & $7.1 \%$ \\
$\mathrm{OH}$ & $\operatorname{mass} \%$ & $\rho$ & $0.740-1.148$ & $\mathrm{RI}$ & $1.422-1.621$ & 0.5 & - \\
\hline
\end{tabular}

* The correlation form is given in Equation.

$\mathrm{M}$ - number average molar mass, $\mathrm{g} \mathrm{mol}{ }^{-1} ; \mathrm{OH}$ - hydroxyl group content, mass $\% ; \rho-$ density, $\mathrm{g} \mathrm{cm}^{3}$; $\mathrm{T}_{\mathrm{b}}$ - average boiling point, $\mathrm{K} ; \mathrm{RI}-$ refractive index

$\mathrm{AAD}^{* *}$ - average absolute deviation

$\mathrm{ARD}^{* * *}$ - average relative deviation

“_“ average relative deviation not calculated because some samples had $\mathrm{OH}$ contents of 0 mass $\%$ 
The reader may notice that the correlation for calculating molar mass from the density and refractive index has a much higher AAD than the other molar mass correlations. However, these AAD values cannot be compared directly because the other correlations based on average boiling point used a smaller range of data. This was because average boiling points could not be measured for the fractions with the highest molar masses due to decomposition in TGA [58]. So we also calculated accuracy metrics for the correlation based on density and refractive index using only the data that also had boiling points measured: the AAD was $12.4 \mathrm{~g} \mathrm{~mol}^{-1}$ and the ARD was $6.2 \%$. Comparing these values with those from the other correlations shows that using the average boiling point does indeed lead to a better prediction of the molar mass. This is to be expected because, as pointed out by Riazi [59], some oil properties describe molecular size and some describe molecular energy. Since the molar mass and the average boiling point are the same type of property, using one to predict the other gives a more accurate correlation.

By contrast, note that the correlation for predicting hydroxyl content from the same inputs (density and refractive index) actually is more accurate. As shown in Figure 3, the density and refractive index are influenced by the concentration of hydroxyl groups in the oil, whereas the average boiling point seems not to be. This could explain why the correlations that use the boiling point perform worse.

\subsection{Connection with other project data}

Other properties were also measured for some of these shale oil samples as part of this project, including vapor pressures, viscosities, surface tensions, sulfur contents, nitrogen contents, pour points, and enthalpies of combustion. The additional data, as well descriptions of the measurement methods used and analysis of the results, has been or will be presented in other articles $[19,53$, 64]. Therefore, this article forms a base for the rest of the data by describing the sample preparation and giving basic characteristics of the samples. The additional articles extend upon this base by more deeply investigating single properties and providing methods for predicting them.

In general, the other articles use the same identifiers provided here which allows the data from different articles to be recombined for further use and analysis. However, some of the earlier articles did not use the same identifiers. One article gave the vapor pressures of three of the fractions [64], and in that article Cut 1R is GR240513-5, Cut 2R is GR240513-8, and Cut 3S is GD071013-5. Another article described the TGA method for measuring average boiling points [53], and the fractions measured came from distillation FR210115. A third described the molecular weight distribution of shale oils [19], and the Galoter SHC oil in that article is sample CG0614. 


\section{Conclusions}

The systematic study undertaken in this project provides the necessary data for comprehensively modeling the properties of kukersite shale oil. The use of vacuum distillation allowed the properties of even heavier portions of the shale oil to be measured than have so far been studied. Based on this data, it was shown that key thermophysical properties of a kukersite shale oil sample can be reliably predicted if two basic properties of the shale oil are known.

By varying the amount of phenolic compounds in the samples, using extraction, it was possible to see that the concentration of polar hydroxyl groups has a significant effect on some properties, such as the density and refractive index. A higher concentration of phenolic compounds generally leads to an increase in the density and refractive index. Thus, it is likely necessary to account for differences in the phenol concentration when modeling and predicting properties of kukersite shale oil.

\section{Acknowledgements}

The authors are grateful for financial support from National Energy R\&D Programs, under Project Nr. AR10129, and from the Estonian Ministry of Education and Research, under Target Financing Nr. SF0140022s10. Eesti Energia AS is gratefully acknowledged for providing shale oil samples.

\section{REFERENCES}

1. Lee, S. Oil Shale Technology. CRC Press, 1990.

2. Oja, V., Suuberg, E. M. Oil Shale Processing, Chemistry and Technology. In: Encyclopedia of Sustainable Science and Technology (Meyers, R. A., ed.). 2012, Springer-Verlag New York, 7457-7491.

3. IPCC. Climate Change 2014: Synthesis Report. Contribution of Working Groups I, II and III to the Fifth Assessment Report of the Intergovernmental Panel on Climate Change. IPCC, Geneva, Switzerland, 2014. https://www.ipcc.ch/report/ ar5/syr/ (accessed Nov. 01, 2019).

4. World Energy Council. World Energy Resources 2016. World Energy Council, London, 2016.

5. Koovit, K. Viru Keemia Group begins construction of oil shale plant. Postimees, Aug. 07, 2012 (in Estonian).

6. Eesti Energia's Enefit 280 oil plant is operating at 70\% capacity. Postimees, Nov. 07, 2014 (in Estonian).

7. Technological indicators of VKG's Petroter III plant exceed expectations. Viru Keemia Grupp. https://www.vkg.ee/vkg-petroter-iii-tehase-tehnoloogilisednaitajad-uletavad-ootusi/ (accessed Nov. 12, 2019). 
8. Sandor Liive presented the oil plant's product - Enefit 280 finally operates stably. Ärileht, Apr. 09, 2014 (in Estonian).

9. Lille, Ü., Heinmaa, I., Pehk, T. Molecular model of Estonian kukersite kerogen evaluated by ${ }^{13}$ C MAS NMR spectra. Fuel, 2003, 82(7), 799-804, doi: 10.1016/ S0016-2361(02)00358-7.

10. Schmidt-Collerus, J. J., Prien, C. H. Investigation of the hydrocarbon structure of kerogen from oil shale of the Green River Formation. Am. Chem. Soc. Div. Fuel Chem. Prepr., 1974, 19(2), 100-108.

11. Robinson, W. E. Kerogen of the Green River Formation. In: Organic Geochemistry (Eglinton, G., Murphy, M. T. J., eds.). Springer Berlin Heidelberg, 1969, 619-637.

12. Urov, K., Sumberg, A. Characteristics of Oil Shales and Shale-Like Rocks of Known Deposits and Outcrops: Monograph. Estonian Acad. Publ., Tallinn, 1999.

13. Bartis, J. T., LaTourrette, T., Dixon, L., Peterson, D. J., Cecchine, G. Oil Shale Development in the United States: Prospects and Policy Issues. Rand Corporation, 2005.

14. Raukas, A., Punning, J.-M. Environmental problems in the Estonian oil shale industry. Energy Environ. Sci., 2009, 2(7), 723-728, doi: 10.1039/B819315K.

15. World Energy Council. World Energy Resources 2013 Survey. World Energy Council, London, 2013.

16. Enefit. Oil Shale Fired Power Plant. https://www.enefit.jo/project/power-plant (accessed Oct. 09, 2020).

17. Al-Khalidi, S. Jordan moves ahead with $\$ 2.1$ bln oil shale power plant. Reuters, March 16, 2017.

18. Zhang, X.-S., Wang, H.-J., Ma, F., Sun, X.-C., Zhang, Y., Song, Z.-H. Classification and characteristics of tight oil plays. Petrol. Sci., 2016, 13(1), 18-33, doi: 10.1007/s12182-015-0075-0.

19. Järvik, O., Oja, V. Molecular weight distributions and average molecular weights of pyrolysis oils from oil shales: Literature data and measurements by size exclusion chromatography (SEC) and atmospheric solids analysis probe mass spectroscopy (ASAPMS) for oils from four different deposits. Energy Fuels, 2016, 31(1), 328339. doi: 10.1021/acs.energyfuels. 6 b02452.

20. Guo, S. H. The chemistry of shale oil and its refining. In: Coal, Oil Shale, Natural Bitumen, Heavy Oil and Peat, Vol. II, 2009, Publishers Company Limited, 94-106.

21. Oja, V., Elenurm, A., Rohtla, I., Tali, E., Tearo, E., Yanchilin, A. Comparison of oil shales from different deposits: Oil shale pyrolysis and co-pyrolysis with ash. Oil Shale, 2007, 24(2), 101-108.

22. Oja, V., Rooleht, R., Baird, Z.S. Physical and thermodynamic properties of kukersite pyrolysis shale oil: Literature review. Oil Shale, 2016, 33(2), 184-197, doi: 10.3176/oil.2016.2.06.

23. Väli, E., Valgma, I., Reinsalu, E. Usage of Estonian oil shale. Oil Shale, 2008, 25(2S), 101-114.

24. Oil shale - Estonia's future. Päevaleht, Aug. 11, 1927, Tallinn, Estonia (in Estonian). 
25. Kattai, V. Oil shale. Eesti Geoloogiakeskus, Tallinn, 2003 (in Estonian).

26. Veidermaa, M. Estonian oil shale - resources and usage. Oil Shale, 2003, 20(3 SPECIAL), 295-303.

27. Soone, J., Doilov, S. Sustainable utilization of oil shale resources and comparison of contemporary technologies used for oil shale processing. Oil Shale, 2003, 20(3 SPECIAL), 311-323.

28. Yefimov, V. Oil shale processing in Estonia and Russia. Oil Shale, 2000, 17(4), $367-385$.

29. Heistand, R. N. Fischer Assay, a standard method. Am. Chem. Soc. Div. Fuel Chem. Prepr., 1976, 21(6), 40-54, American Chemical Society meeting, San Francisco, California, USA (29 Aug 1976).

30. Luts, K. The Estonian Oil Shale Kukersite, its Chemistry, Technology and Analysis (Der estländische Brennschiefer-Kukersit, seine Chemie, Tehnologie und Analyse). K. Mattiesens Buchdruckerei Ant.-Ges., Tartu, Estonia, 1934.

31. Yefimov, V. M., Rooks, I. H. The Kiviter process for retorting large particle oil shale. In: Oil Shale Symposium Proceedings (USA), 1989, 22, 256-263.

32. Viru Keemia Grupp. Technology. https://www.vkg.ee/en/technology/ (accessed Nov. 20, 2020).

33. Golubev, N. Solid oil shale heat carrier technology for oil shale retorting. Oil Shale, 2003, 20(3 SPECIAL), 324-332.

34. Blinova, E. A., Veldre, I. A., Jänes, H. J. The Toxicology of Shale Oils and Phenols. Valgus, Tallinn, 1974 (in Russian).

35. Kollerov, D. K. Physicochemical Properties of Oil Shale and Coal Liquids. Moscow, 1951 (in Russian).

36. Barschevski, M. M., Bezmozgin, E. S., Shapiro, R. N. Handbook of Oil Shale Processing. Gostopizdat, Leningrad, 1963 (in Russian).

37. Zelenin, N. I. Shale Oil Liquid Fuel. Gostoptekhizdat, Leningrad, 1948 (in Russian).

38. Zelenin, N. I. The composition and properties and potential uses of shale oils. In: VNIIPS Proceedings, 1958, 7 (in Russian).

39. Sheloumov, V. V., Epstein, S. A. Semicoking oil shale in tunnel ovens. In: Oil Shale Compilation. Chemistry and Technology. 1956 (in Russian).

40. Aarna, A., Kask, K. About the determination of the group composition of middle oil fractions of shale oil by chromatographic analysis. Proceedings of Tallinn Polytechnic Institute, Series A, 1953, No. 51 (in Russian).

41. Epstein, S. A., Sheloumov, V. V., Kuznetsov, D. T. Experience from technoeconomical comparison of methods of semicoking Baltic oil shale. In: Compilation of Questions Concerning Technology and Economics of the Oil Shale Semicoking Industry 1959, 2, Leningrad, Gostoptekhizdat (in Russian).

42. Ründal, L. J. Calculation method for determining the chemical composition of shale gas. In: Proceedings of Tallinn Polytechnical Institute, Series A. 1956, 73, 109-114 (in Estonian).

43. Kogerman, P. N. On the Chemistry of the Estonian Oil Shale "Kukersite”. Oil Shale Research Laboratory, Tartu, Estonia, 1931. 
44. Qian, J., Yin, L. Oil Shale: Petroleum Alternative. China Petrochemical Press, 2010.

45. Oja, V., Rooks, I., Elenurm, A, Martins, A., Uus, E., Milk, A. An evaluation of the potential for application of gasification technology for oil shale production in Estonia. Chemical Engineering Department, Tallinn University of Technology, Tallinn, 2006 (in Estonian).

46. Maaten, B., Järvik, O., Pihl, O., Konist, A., Siirde, A. Oil shale pyrolysis products and the fate of sulfur. Oil Shale, 2020, 37(1), 51-69.

47. Eisen, O. G., Rang, S. A. Individual Composition of Shale Oil Hydrocarbons. Institute of Chemistry, Academy of Sciences of Estonian SSR, Tallinn, 1968.

48. Gubergrits, M. J., Rohtla, I., Elenurm, A., Myasoyedov, A. M. Comparison of light oil products from oil shale retorting in solid heat carrier units UTT-3000 and UTT-500. Oil Shale, 1989, 6(2), 189-194 (in Russian).

49. Baird, Z. S., Oja, V., Järvik, O. Distribution of hydroxyl groups in kukersite shale oil: Quantitative determination using Fourier transform infrared (FT-IR) spectroscopy. Appl. Spectrosc., 2015, 69(5), 555-562, doi: 10.1366/14-07705.

50. Baird, Z. S. Predicting Fuel Properties from Infrared Spectra. PhD thesis, Tallinn University of Technology, TUT Press, Tallinn, Estonia, 2017.

51. ASTM D86. Standard Test Method for Distillation of Petroleum Products at Atmospheric Pressure. ASTM International, West Conshohocken, PA, USA, 2012.

52. ASTM D2892. Standard Test Method for Distillation of Crude Petroleum (15-Theoretical Plate Column). ASTM International, West Conshohocken, PA, USA, 2016.

53. Rannaveski, R., Järvik, O., Oja, V. A new method for determining average boiling points of oils using a thermogravimetric analyzer. J. Therm. Anal. Calorim., 2016, 126, 1679-1688, doi: 10.1007/s10973-016-5612-6.

54. ISO 647:1974. Brown Coals and Lignites - Determination of the Yields of Tar, Water, Gas and Coke Residue by Low Temperature Distillation. International Organization for Standards, 2009.

55. Baird, Z. S., Uusi-Kyyny, P., Oja, V., Alopaeus, V. Hydrogen solubility of shale oil containing polar phenolic compounds. Ind. Eng. Chem. Res., 2017, 56(30), 8738-8747, doi: 10.1021/acs.iecr.7b00966.

56. Baird, Z. S., Uusi-Kyyny, P., Järvik, O., Oja, V., Alopaeus, V. Temperature and pressure dependence of density of a shale oil and derived thermodynamic properties. Ind. Eng. Chem. Res., 2018, 57(14), 5128-5135, doi: 10.1021/acs. iecr.7b05018.

57. ASTM D2224. Method of Test for Mean Molecular Weight of Mineral Insulating Oils by the Cryoscopic Method. ASTM International, West Conshohocken, PA, USA, 1983.

58. Rannaveski, R. Developing a Novel Method for Using Thermal Analysis to Determine Average Boiling Points of Narrow Boiling Range Continuous Mixtures. PhD thesis, Tallinn University of Technology, Tallinn, Estonia, 2018 (in Estonian). 
59. Riazi, M. R. Characterization and Properties of Petroleum Fractions. ASTM International, 2005.

60. Riazi, M. R., Daubert, T. E. Characterization parameters for petroleum fractions. Ind. Eng. Chem. Res., 1987, 26(4), 755-759, doi: 10.1021/ie00064a023.

61. Storn, R., Price, K. Differential evolution - a simple and efficient heuristic for global optimization over continuous spaces. J. Glob. Optim., 1997, 11(4), 341359, doi: 10.1023/A:1008202821328.

62. Jones, E., Oliphant, T., Peterson, P. SciPy: Open Source Scientific Tools for Python. 2001. http://www.scipy.org/ (accessed Sep. 28, 2016).

63. Rousseeuw, P. J., Leroy, A. M. Robust Regression and Outlier Detection. John Wiley \& Sons, 2005.

64. Siitsman, C., Oja, V. Extension of the DSC method to measuring vapor pressures of narrow boiling range oil cuts. Thermochim. Acta, 2015, 622, 31-37, doi: 10.1016/j.tca.2015.04.011. 


\section{Appendix}

Table A1. Composition of kukersite shale gasoline (mass \%) from different retorts $[34,36,40,45,47]$

\begin{tabular}{|c|c|c|c|c|c|}
\hline Chemical composition, \%mass & Tunnel oven & Rotating & $\begin{array}{c}\text { Chamber } \\
\text { oven }\end{array}$ & Kiviter & Galoter \\
\hline n-Alkanes & 18.7 & 34 & 9.2 & 13.9 & \\
\hline Isoalkanes & 0.9 & & 0.3 & & \\
\hline Cyclopentanes & 1.9 & & 0.6 & & 17.4 \\
\hline Cyclohexanes & 1.6 & & 0.6 & & \\
\hline n-Alkenes & 32.9 & & 10.2 & 40.7 & \\
\hline Isoalkenes & 1.6 & & 0.3 & & \\
\hline Cyclopentenes & 4.3 & & 0.7 & & 57.4 \\
\hline Cyclohexenes & 4.6 & & 0.8 & & \\
\hline Diolefins & 0.5 & & 3.4 & & \\
\hline Aromatic compounds & 8.5 & & 61.7 & 22.4 & 11.4 \\
\hline Sulfuric compounds & 0.7 & & 0.8 & & \\
\hline $\begin{array}{l}\text { Unidentified saturated } \\
\text { hydrocarbons }\end{array}$ & 3.8 & & 0.2 & & \\
\hline $\begin{array}{l}\text { Unidentified unsaturated } \\
\text { hydrocarbons }\end{array}$ & 15 & 55.6 & 3.8 & & \\
\hline $\begin{array}{l}\text { Unidentified aromatics, } \\
\text { oxygen containing and sulfuric } \\
\text { containing compounds }\end{array}$ & 5 & 10.4 & 7.4 & 16.2 & 12.0 \\
\hline Phenols & $\begin{array}{l}\text { Included } \\
\text { in oxygen } \\
\text { containing } \\
\text { compounds }\end{array}$ & & & 6.7 & 1.8 \\
\hline
\end{tabular}




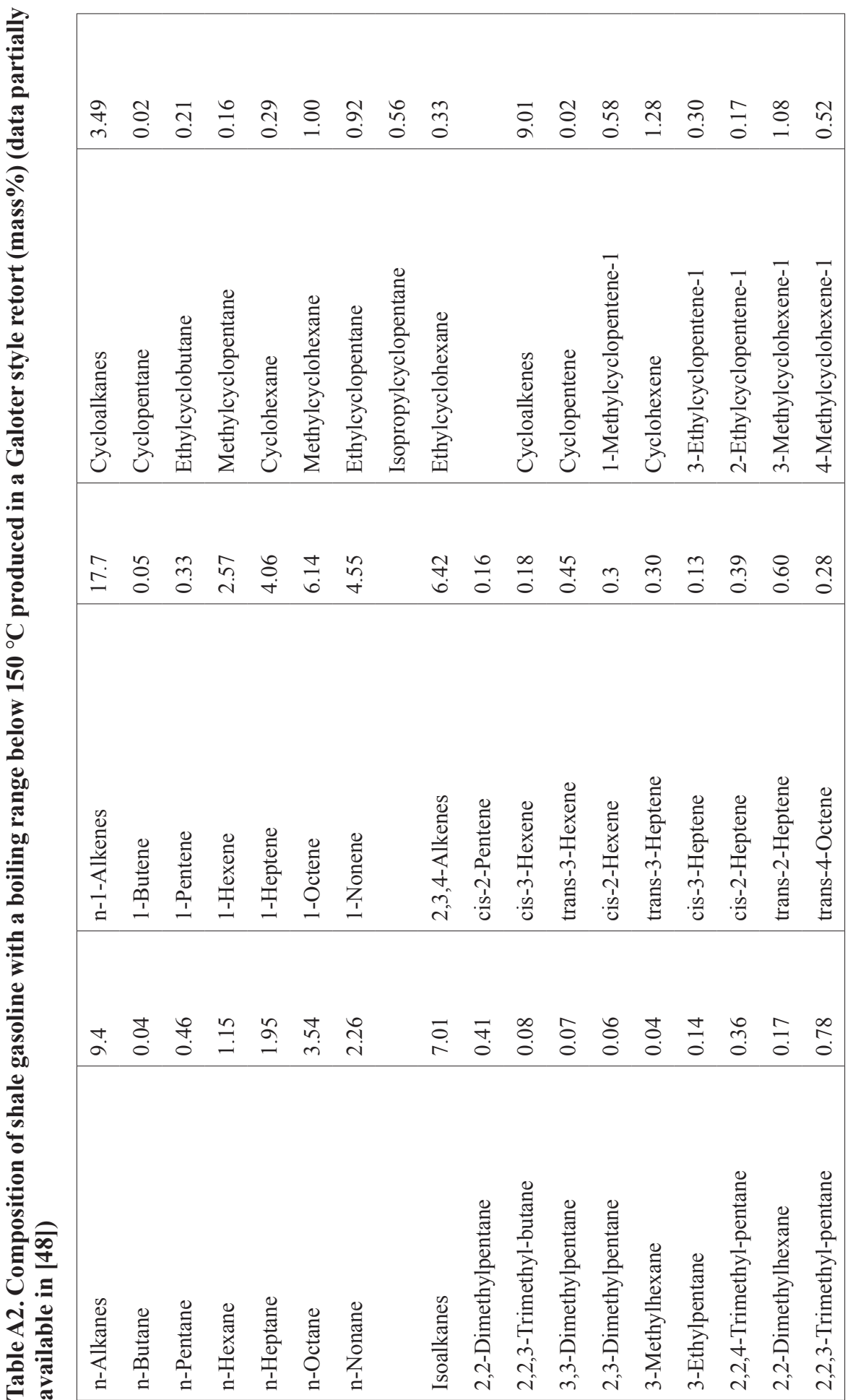




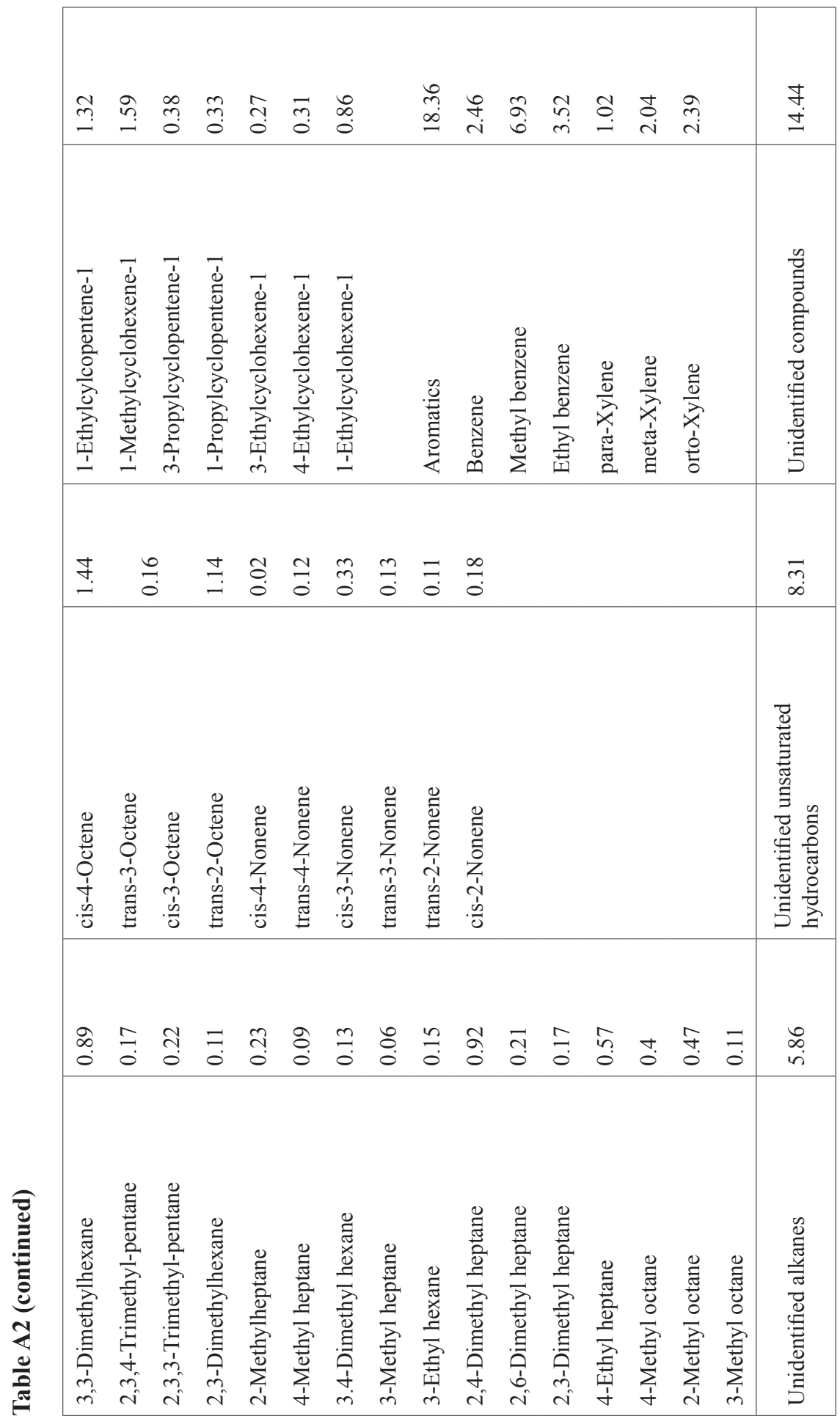




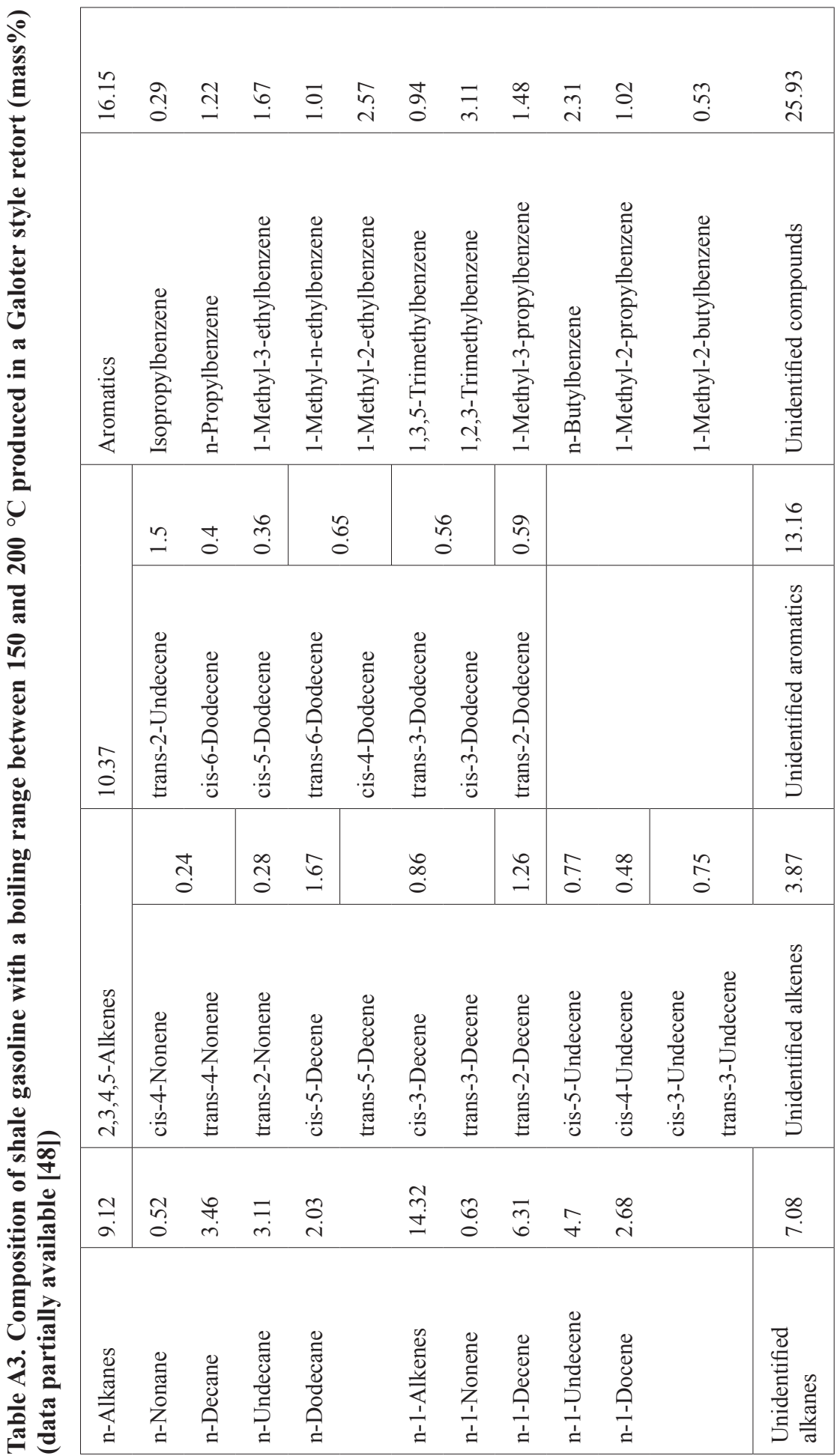




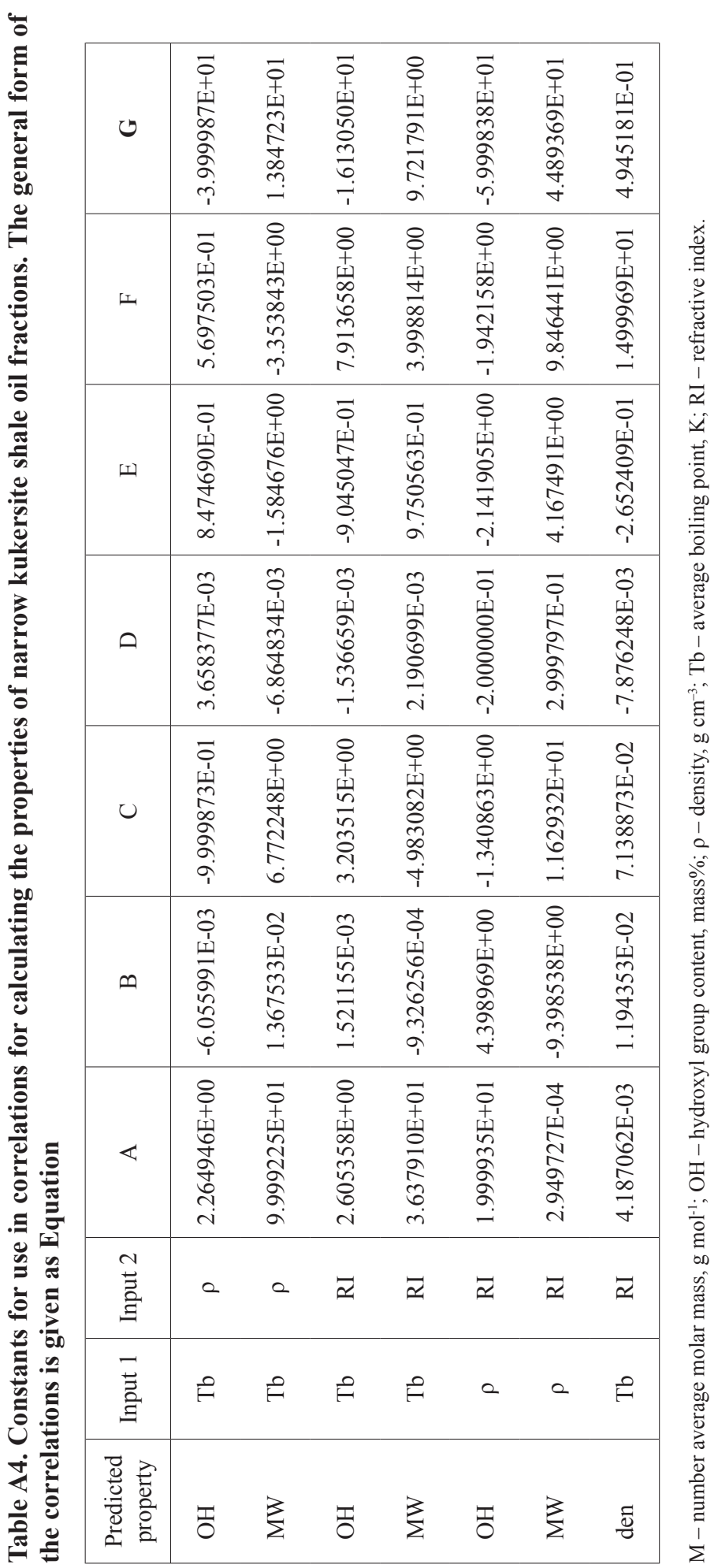

